Prepared in cooperation with the City of Hattiesburg, City of Petal, Forrest County, Mississippi Emergency Management Agency, Mississippi Department of Homeland Security, and the Emergency Management District

Prepared in collaboration with the National Weather Service

\title{
An Expanded Model: Flood-Inundation Maps for the Leaf River at Hattiesburg, Mississippi, 2013
}
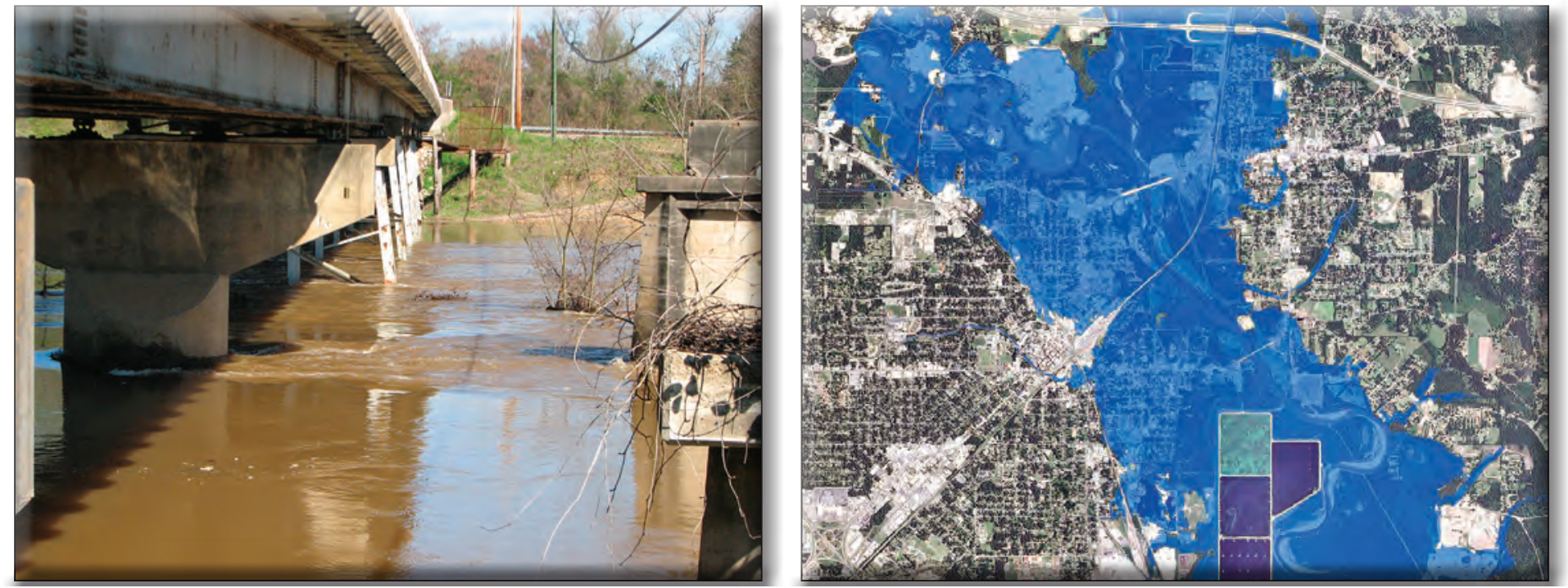

Pamphlet to accompany

Scientific Investigations Map 3300 
Cover. Left, photograph looking at the downstream side of the bridge at Bouie River at Glendale Avenue at Hattiesburg, Mississippi (02472980), February 14, 2013. Right, inundation map of Leaf River at Hattiesburg, Mississippi (02473000), at 34.0 feet gage datum (see Sheet 13 for details). 


\section{An Expanded Model: Flood-Inundation Maps for the Leaf River at Hattiesburg, Mississippi, 2013}

By John B. Storm

Prepared in cooperation with the City of Hattiesburg, City of Petal, Forrest County, Mississippi Emergency Management Agency, Mississippi Department of Homeland Security, and the Emergency Management District

Prepared in collaboration with the National Weather Service

Pamphlet to accompany

Scientific Investigations Map 3300 


\title{
U.S. Department of the Interior \\ SALLY JEWELL, Secretary
}

\section{U.S. Geological Survey \\ Suzette M. Kimball, Acting Director}

\section{U.S. Geological Survey, Reston, Virginia: 2014}

\author{
For more information on the USGS — the Federal source for science about the Earth, its natural and living resources, \\ natural hazards, and the environment, visit http://www.usgs.gov or call 1-888-ASK-USGS \\ For an overview of USGS information products, including maps, imagery, and publications, \\ visit $h t t p: / / w w w . u s g s . g o v / p u b p r o d$ \\ To order this and other USGS information products, visit http://store.usgs.gov
}

Any use of trade, product, or firm names is for descriptive purposes only and does not imply endorsement by the U.S. Government.

Although this report is in the public domain, permission must be secured from the individual copyright owners to reproduce any copyrighted materials contained within this report.

Suggested citation:

Storm, J.B., 2014, An expanded model—Flood-inundation maps for the Leaf River at Hattiesburg, Mississippi, 2013: U.S. Geological Survey Scientific Investigations Map 3300, 13 sheets, 8-p. pamphlet, http://dx.doi.org/10.3133/ $\operatorname{sim} 3228$.

ISSN 2329-132X (online) 


\section{Contents}

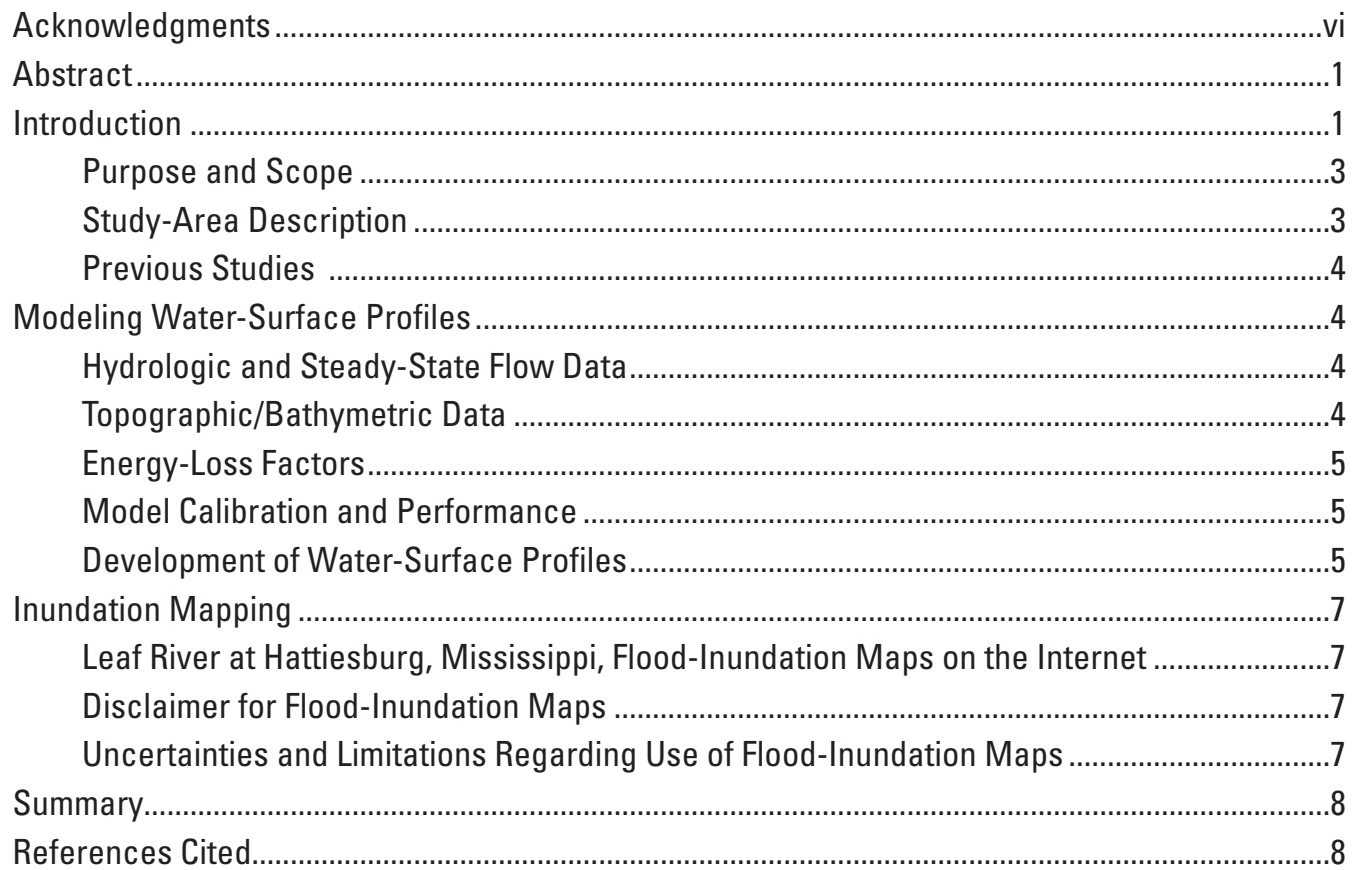

\section{Figure}

1. Map showing location of the study reach for the Leaf River and location of USGS streamgages and National Weather Service forecast site

\section{Tables}

1. USGS streamgage and miscellaneous site information for the study basin, Leaf River at Hattiesburg, Mississippi.

2. 1.0-percent annual exceedance probability peak-discharge estimates, drainage areas, and percentage of total discharge for selected locations on the Leaf River

3. Comparison of hydraulic-model output and water-surface elevations at the Leaf River at Hattiesburg, Mississippi, streamgage 02473000

4. Comparison of hydraulic-model output and surveyed high-water mark elevations from the floods of April 15, 1974, and March 11, 2011, at the Leaf River at Hattiesburg, Mississippi, streamgage 02473000.

5. Stages and water-surface elevations at the Leaf River at Hattiesburg, Mississippi, streamgage 02473000, with corresponding discharge estimates for selected simulated water-surface profiles. 


\section{Sheets}

[Sheets and additional materials are available online at http://pubs.usgs.gov/sim/3300/.]

1-13. Estimated flood-inundation maps for the Leaf River at Hattiesburg, Mississippi, referenced to USGS streamgage Leaf River at Hattiesburg, Mississippi (sta. no. 02473000) for stream stages of:

1. Gage height of 22.0 feet and an elevation of 140.18 feet

2. Gage height of 23.0 feet and an elevation of 141.18 feet

3. Gage height of 24.0 feet and an elevation of 142.18 feet

4. Gage height of 25.0 feet and an elevation of 143.18 feet

5. Gage height of 26.0 feet and an elevation of 144.18 feet

6. Gage height of 27.0 feet and an elevation of 145.18 feet

7. Gage height of 28.0 feet and an elevation of 146.18 feet

8. Gage height of 29.0 feet and an elevation of 147.18 feet

9. Gage height of 30.0 feet and an elevation of 148.18 feet

10. Gage height of 31.0 feet and an elevation of 149.18 feet

11. Gage height of 32.0 feet and an elevation of 150.18 feet

12. Gage height of 33.0 feet and an elevation of 151.18 feet

13. Gage height of 34.0 feet and an elevation of 152.18 feet 


\section{Conversion Factors and Datums}

\begin{tabular}{lcl}
\multicolumn{1}{c}{ Inch/Pound to SI } & By & \multicolumn{1}{c}{ To obtain } \\
\hline & Length & millimeter $(\mathrm{mm})$ \\
\hline inch & 25.4 & meter $(\mathrm{m})$ \\
foot $(\mathrm{ft})$ & 0.3048 & kilometer $(\mathrm{km})$ \\
mile $(\mathrm{mi})$ & 1.609 & \\
\hline & Area & square meter $\left(\mathrm{m}^{2}\right)$ \\
\hline square foot $\left(\mathrm{ft}^{2}\right)$ & 0.0929 & square kilometer $\left(\mathrm{km}^{2}\right)$ \\
square mile $\left(\mathrm{mi}^{2}\right)$ & 2.590 & \\
\hline & Flow rate & cubic meter per second $\left(\mathrm{m}^{3} / \mathrm{s}\right)$ \\
\hline cubic foot per second $\left(\mathrm{ft}^{3} / \mathrm{s}\right)$ & 0.02832 & meter per $\mathrm{kilometer}(\mathrm{m} / \mathrm{km})$ \\
\hline
\end{tabular}

Vertical coordinate information is referenced to the North American Vertical Datum of 1988 (NAVD 88).

Horizontal coordinate information is referenced to the North American Datum of 1983 (NAD 83).

Elevation, as used in this report, refers to the distance above NAVD 88.

Stage, as used in this report, is the height of the water surface above an arbitrary datum established at the gage (gage datum).

\section{Abbreviations}

$\begin{array}{ll}\text { AHPS } & \text { Advanced Hydrologic Prediction Service } \\ \text { DEM } & \text { digital elevation model } \\ \text { DGPS } & \text { differential global positioning system } \\ \text { FEMA } & \text { Federal Emergency Management Agency } \\ \text { FIS } & \text { Flood Insurance Study } \\ \text { GIS } & \text { geographic information system } \\ \text { lidar } & \text { light detection and ranging } \\ \text { NWS } & \text { National Weather Service } \\ \text { USGS } & \text { U.S. Geological Survey }\end{array}$




\section{Acknowledgments}

The author wishes to thank the many local, State, and Federal agencies that have cooperated in the funding for the operation and maintenance of the gages used for this study, especially the Mississippi Department of Environmental Quality. Special thanks are given to the City of Hattiesburg, City of Petal, Forrest County, Mississippi Emergency Management Agency, Mississippi Department of Homeland Security, and the Emergency Management District for their cooperation in this study and to the National Weather Service for their continued support to the USGS flood-inundation mapping initiative. 


\title{
An Expanded Model: Flood-Inundation Maps for the Leaf River at Hattiesburg, Mississippi, 2013
}

\author{
By John B. Storm
}

\section{Abstract}

Digital flood-inundation maps for a 6.8-mile reach of the Leaf River at Hattiesburg, Mississippi (Miss.), were created by the U.S. Geological Survey (USGS) in cooperation with the City of Hattiesburg, City of Petal, Forrest County, Mississippi Emergency Management Agency, Mississippi Department of Homeland Security, and the Emergency Management District. The inundation maps, which can be accessed through the USGS Flood Inundation Mapping Science Web site at http://water.usgs.gov/osw/flood_inundation/, depict estimates of the areal extent and depth of flooding corresponding to selected water levels (stages) at the USGS streamgage at Leaf River at Hattiesburg, Miss. (station no. 02473000). Current conditions for estimating near-real-time areas of inundation by use of USGS streamgage information may be obtained on the Internet at http://waterdata.usgs.gov/. In addition, the information has been provided to the National Weather Service (NWS) for incorporation into their Advanced Hydrologic Prediction Service (AHPS) flood warning system (http:/water.weather.gov/ahps/). The NWS forecasts flood hydrographs at many places that are often colocated with USGS streamgages. NWS-forecasted peak-stage information may be used in conjunction with the maps developed in this study to show predicted areas of flood inundation.

In this study, flood profiles were computed for the stream reach by means of a one-dimensional step-backwater model. The model was calibrated by using the most current stage-discharge relations at the Leaf River at Hattiesburg, Miss. streamgage (02473000) and documented high-water marks from recent and historical floods. The hydraulic model was then used to determine 13 water-surface profiles for flood stages at 1.0-foot intervals referenced to the streamgage datum and ranging from bankfull to approximately the highest recorded water level at the streamgage. The simulated water-surface profiles were then combined with a geographic information system (GIS) digital elevation model (DEM, derived from light detection and ranging (lidar) data having a 0.6-foot vertical and 9.84-foot horizontal resolution) in order to delineate the area flooded at each water level.
Development of the estimated flood inundation maps as described in this report update previously published inundation estimates by including reaches of the Bouie and Leaf Rivers above their confluence. The availability of these maps along with Internet information regarding current stage from USGS streamgages and forecasted stream stages from the NWS provide emergency management personnel and residents with information that is critical for flood response activities such as evacuations and road closures as well as for post flood recovery efforts.

\section{Introduction}

The City of Hattiesburg is a medium-sized urban community (4th largest city in Mississippi) with an estimated population of 45,989 (U.S. Census Bureau, 2010). Hattiesburg, which is in Forrest County, has experienced severe flooding numerous times, most notably the four largest floods occurring during the past 100 years in 1920, 1921, 1961, and 1974. These floods also affected the City of Petal, which is located directly across the Leaf River from Hattiesburg (fig. 1). Damage costs not adjusted for inflation within the cities of Hattiesburg and Petal were reported to be $\$ 3.25$ million (Wilson, 1964) and \$8.3 million (U.S. Army Corps of Engineers, 1983) for the 1961 and 1974 floods, respectively. The majority of flood damages have occurred along the Leaf River and a couple of tributaries (Bouie River and Gordon Creek), both of which flow through Hattiesburg. Flood plains within Hattiesburg are moderately developed and contain a mix of residential and commercial structures.

Prior to this study, Hattiesburg and Petal officials relied on several information sources, all of which are available on the Internet, to make decisions on how to best alert the public and mitigate flood damages. One source is the Federal Emergency Management Agency (FEMA) Flood Insurance Study (FIS) for Forrest County dated March 2, 2010 (Federal Emergency Management Agency, 2010). A second source of information is the U.S. Geological Survey (USGS) Leaf River at Hattiesburg Miss. streamgage (station no. 02473000), 


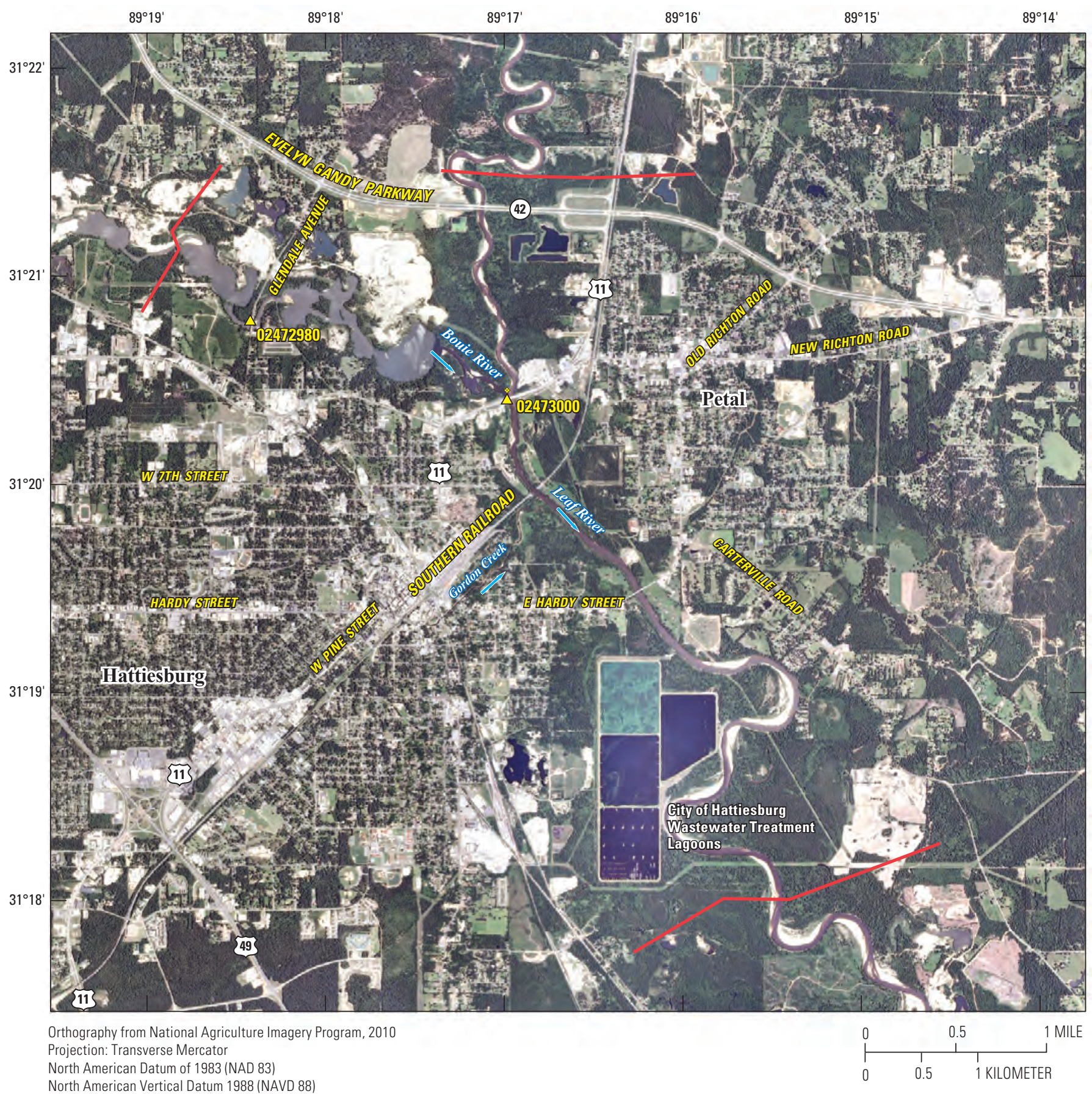

North American Vertical Datum 1988 (NAVD 88)

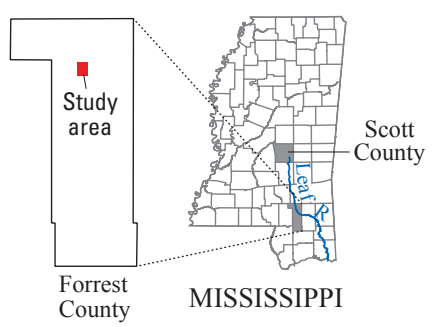

\section{EXPLANATION}

Study area boundary

$\longrightarrow$ Direction of surface-water flow

$\triangle_{02473000}$ USGS streamgage and National Weather Service forecast site and identifier

$\triangle_{02472980}$ USGS streamgage and identifier

Figure 1. Location of the study reach for the Leaf River and location of USGS streamgages and National Weather Service forecast site. 
from which current or historical water levels (stage) can be obtained. A third source is the National Weather Service's (NWS) forecast of peak stage at the USGS gage through the Advanced Hydrologic Prediction Service (AHPS) site. Although USGS current stage and NWS forecast stage information is particularly useful for residents in the immediate vicinity of a streamgage, it is of limited use to residents farther upstream or downstream because the water-surface elevation is not constant along the entire stream channel. Also, FEMA and State emergency management mitigation teams or property owners typically lack information related to how deep the water is at locations other than near USGS streamgage or NWS flood-forecast points.

Beginning in October 2010, the USGS in cooperation with the City of Hattiesburg initiated a study to develop flood inundation maps for the City of Hattiesburg. This study included reaches on both the Bouie and Leaf Rivers in Hattiesburg and was designed to reference an existing USGS streamgage on the Leaf River and an added gage on the Bouie River.

\section{Purpose and Scope}

This report describes the development of a series of estimated flood-inundation maps for the Leaf River at Hattiesburg, Miss. These maps supersede previously published flood-inundation estimates (Storm, 2012) and expand the spatial scope of earlier work to include reaches above the confluence of the Bouie and Leaf Rivers. These updated maps and other useful flood information are available on the USGS Flood Inundation Mapping Science Web site and the NWS Advanced Hydrologic Prediction Service Web site. Internet users can select estimated inundation maps that correspond to (1) current stages at the USGS streamgage, or (2) the NWS forecasted peak stage.

The scope of analysis described in this report is spatially limited to a 6.8-mile (mi) reach of the Leaf River between the Evelyn Gandy Parkway (State Road 42) and the Hattiesburg wastewater treatment lagoons downstream as well as a 2.2-mi reach of the Bouie River between Glendale Avenue and its confluence with the Leaf River (fig. 1). Six procedural and analytical steps in the production of inundation maps are also described. These include: (1) examination of current and historical data at streamgages in the study reach (table 1), (2) collection of topographic data and geometric data (for structures/bridges) throughout the study reach, (3) determination of energy-loss factors (roughness coefficients) in the stream channel and flood plain and compilation of steady-flow data, (4) computation of water-surface profiles by use of the U.S. Army Corps of Engineers HEC-RAS computer program (U.S. Army Corps of Engineers, 2010), (5) production of estimated flood-inundation maps at various stream stages by use of the U.S. Army Corps of Engineer's HEC-GeoRas computer program (U.S. Army Corps of Engineers, 2009) and a geographic information system (GIS), and (6) development of a Web interface that links to USGS real-time streamgage information and (or) NWS forecasted peak stage to facilitate the display of user-selected flood-inundation maps on the Internet.

Methods used are generally cited from previously published reports. If techniques varied substantially from previously documented methods because of local hydrologic conditions or availability of data, they are described in detail in this report. Maps were produced for water levels referenced to the stage at Leaf River at Hattiesburg, Miss. (02473000) and range from approximately bankfull to the maximum observed water level at the streamgage.

\section{Study-Area Description}

The Leaf River is in southeast Mississippi in the East Gulf Coastal Plain. The drainage area ranges from approximately 1,074 square miles $\left(\mathrm{mi}^{2}\right)$ at the upstream extent of the study reach to $1,748 \mathrm{mi}^{2}$ at the Leaf River at Hattiesburg Miss. streamgage to $1,773 \mathrm{mi}^{2}$ at the downstream extent of the study reach. The headwaters originate in Scott County, and the stream flows generally southward before entering the city limits. The Bouie River is a major tributary to the Leaf River and joins the main stem as it flows through Hattiesburg. The Bouie River confluence with the Leaf River is approximately

Table 1. USGS streamgage and miscellaneous site information for the study basin, Leaf River at Hattiesburg, Mississippi.

$\left[\mathrm{mi}^{2}\right.$, square mile; ft, foot; ${ }^{\circ}$, degree; ', minute; ", second; NAVD 88, North American Vertical Datum of 1988]

\begin{tabular}{|c|c|c|c|c|c|c|}
\hline Station name & $\begin{array}{l}\text { Station } \\
\text { number }\end{array}$ & $\begin{array}{l}\text { Drainage } \\
\text { area } \\
\left(\mathrm{mi}^{2}\right)\end{array}$ & Latitude & Longitude & Period of record & $\begin{array}{l}\text { Maximum recorded } \\
\text { stage at gage } \\
\text { (ft above gage datum) } \\
\text { and date }\end{array}$ \\
\hline
\end{tabular}


0.1 mi upstream of the Leaf River at Hattiesburg Miss. streamgage and has a drainage area of $674 \mathrm{mi}^{2}$. The basin terrain is generally flat, and most of the basin is rural. The study reach is approximately $6.8 \mathrm{mi}$ long and has an average top-of-bank channel width of about 350 feet (ft) and an average channel slope of 1.8 feet per mile ( $\mathrm{ft} / \mathrm{mi})$. About 47 percent of the land contiguous to the study reach is classified as urban or developed, 25 percent as forest, and 6 percent as cropland. The basin is still under development, as evidenced by a population increase of 2.7 percent from 44,779 to 45,989 between 2000 and 2010 (U.S. Bureau of Census, 2010). The main channel within the study reach has four major road crossings and one railroad crossing that lie within the channel or the adjacent flood plain.

\section{Previous Studies}

The current FIS for Forrest County (Federal Emergency Management Agency, 2010) was completed by Neel-Schaffer, Inc., in 1990 and revised by the State of Mississippi in 2010. That study provided information on the 1.0- and 0.2-percent annual exceedance probability water-surface profiles and associated flood-plain maps for the Leaf River and Bouie River. Estimates of the peak discharges for the 1.0-percent annual exceedance probability flood along the Leaf River, as listed in table 2 below for the study reach, are described by the Federal Emergency Management Agency (2010).

In the report by Storm (2012), flood inundation maps were estimated only for reaches of the Leaf River below the confluence with the Bouie River due to budget and time constraints. These initial flood estimates provided an intermediate product for cooperating agencies until analyses for the upper portion of the study area could be completed for the project as described in this report.

Table 2. 1.0-percent annual exceedance probability peakdischarge estimates, drainage areas, and percentage of total discharge for selected locations on the Leaf River (from Federal Emergency Management Agency, 2010).

$\left[\mathrm{mi}^{2}\right.$, square mile; $\mathrm{ft}^{3} / \mathrm{s}$, cubic foot per second]

\begin{tabular}{lcc}
\hline $\begin{array}{c}\text { Location on } \\
\text { Leaf River }\end{array}$ & $\begin{array}{c}\text { Drainage area } \\
\left(\mathbf{m i}^{2}\right)\end{array}$ & $\begin{array}{c}\text { Discharge estimate } \\
\left(\mathbf{f t}^{\mathbf{3}} \mathbf{s}\right)\end{array}$ \\
\hline At U.S. Highway 11 & 1,760 & 110,000 \\
$\begin{array}{l}\text { Upstream from Bouie } \\
\text { River confluence }\end{array}$ & 1,100 & 82,000 \\
\hline
\end{tabular}

\section{Modeling Water-Surface Profiles}

HEC-RAS, version 4.1.0 (U.S. Army Corps of Engineers, 2010) was used to produce longitudinal water-surface profiles at $1.0-\mathrm{ft}$ increments between $22.0 \mathrm{ft}$ and $34.0 \mathrm{ft}$ of stage on the Leaf River at Hattiesburg, Miss. (02473000). HEC-RAS is a one-dimensional step-backwater model for simulation of water-surface profiles with gradually varied, steady-state (or unsteady-state) flow computation options. The HEC-RAS analysis for this study was done by using the steady-state flow computation option. The information required to drive and calibrate HEC-RAS for the Leaf River included hydrologic data and steady-state flow conditions, channel geometry at multiple cross sections, and estimates of channel roughness. This model was calibrated to the most current (2012) stage-discharge relation at the Leaf River streamgage and to high-water marks from the floods on April 15, 1974, and March 11, 2011.

\section{Hydrologic and Steady-State Flow Data}

The study-area hydrologic network consists of two streamgages (fig. 1; table 1). The Leaf River gage is a longterm continuously operating gage. The Bouie River gage was constructed and equipped with a continuous recorder at the beginning of this study in 2010. Water levels (stage) are measured continuously and continuous records of streamflow are computed for both sites. All water-surface elevations are referenced to the North American Vertical Datum of 1988 (NAVD 88). The gages are equipped with satellite radio transmitters that allow data to be transmitted routinely on the Internet within an hour of collection. The Leaf River gage is also equipped with a recording tipping-bucket rain gage. Longitudinal water-surface profiles from high-water marks along the main channel were documented following the peak of record flood in 1974 and during a bankfull event in 2011. These water-surface profiles were used for model calibration.

Steady-state flow data consisted of selected flow-regime characteristics, boundary conditions (including either observed stage associated with a discharge measurement, critical depth, normal depth, or streamgage rating-curve value), and peak-discharge information. The steady-state flow data for the study reach were obtained from previous studies and field measurements of streamflow at the Leaf River at Hattiesburg Miss. streamgage or at miscellaneous sites. At gaged sites, all computations based on discharge values with known stages from actual streamflow measurements or stage-discharge relations were used. For ungaged sites, normal-depth boundary conditions were assumed by using a friction slope estimated from the average streambed slope through the reach unless miscellaneous discharge measurements referenced to a known datum were available.

\section{Topographic/Bathymetric Data}

Channel cross sections were developed from USGS field surveys that were conducted from 1990 to 2011; these cross sections provide detailed channel-elevation data below the water surface and were collected using hydroacoustic instrumentation and mechanical means to measure depth and horizontal distance at all five hydraulic structures within the 
study area. Differential Global Positioning System (DGPS) instrumentation was used to determine vertical control at the hydraulic structures. Lidar data were collected in the area in March and April 2006 by EarthData International, Inc. (written commun., 2007) and postprocessed in 2007. These data provided horizontal resolution of $9.84 \mathrm{ft}$ and vertical accuracy of $0.6 \mathrm{ft}$ and were used to provide digital elevation data for the portions of the cross sections that were above the water surface at the time of the surveys.

Various manmade drainage structures such as bridges, culverts, roadway embankments, levees, and dams can affect water-surface elevations during floods. To properly account for these features in the Leaf River model, structural dimensions for five bridges were measured and surveyed in the field concurrently with the stream-channel surveys. A detailed description of the methods used to acquire and process the topographic and bathymetric data can be found in Bales and others (2007).

\section{Energy-Loss Factors}

Field observations and high-resolution aerial photographs were used to select initial (precalibration) Manning's roughness coefficients (" $n$ " values) for energy-loss (friction-loss) calculations. The final Manning's $n$ values used ranged from 0.024 to 0.048 for the main channel and 0.050 to 0.28 for the overbank areas modeled in this analysis.

\section{Model Calibration and Performance}

The model was calibrated by adjusting roughness values (Manning's $n$ ) and channel geometry (cross-sectional area and slope) to bring hydraulic computations into agreement with the observed flood-discharge and stage values. The estimated peak discharge for the 1974 flood was 121,000 cubic feet per second $\left(\mathrm{ft}^{3} / \mathrm{s}\right)$ at an estimated stage of $34.03 \mathrm{ft}$ at the gage and the measured peak discharge for the 2011 flood was $33,400 \mathrm{ft}^{3} / \mathrm{s}$ at a stage of $21.34 \mathrm{ft}$. Differences between measured and simulated water levels for measured or rated flows at USGS streamgage 02473000 were equal to or less than $0.17 \mathrm{ft}$ (table 3). Differences between measured and simulated water levels for models calibrated to high-water marks in the study reach were equal to or less than $0.14 \mathrm{ft}$ (table 4). The results demonstrate that the model is capable of simulating accurate water levels over a wide range of flows in the basin. Details on techniques used in model development and calibration can be found in Bales and others (2007).

\section{Development of Water-Surface Profiles}

Discharges corresponding to the various stages were obtained from the most current stage-discharge relation (rating no. 29.0) at the Leaf River gage. Discharges for all profiles (table 5) at locations downstream of the Leaf River streamgage (02473000) were held constant because of the relatively small amount of contributing drainage that enters the Leaf River within this part of the study reach. Tributaries entering the reach below the streamgage will most likely be ineffective during a flood event because of backwater storage for floodwaters from the Leaf River. There is a possibility of localized heavy rainfall contributing to the backwater inundation areas, but estimating the probability and quantity of such contributions is beyond the scope of this report.

The Bouie River is a major tributary to the Leaf River and its confluence is approximately $0.1 \mathrm{mi}$ above the Leaf River streamgage (02473000). A streamgage on the Bouie River at Glendale Avenue (02472980) has been in operation since October 1, 2010. There have been no flood events greater than the flood stage $(22.0 \mathrm{ft})$ as defined by the NWS at the Leaf River gage during the period of record at the Bouie River gage. A conservative flow distribution of approximately $70 / 30$ in the Leaf and Bouie Rivers respectively, above the confluence, was assumed based on the discharge rating at the Bouie River streamgage.

Table 3. Comparison of hydraulic-model output and water-surface elevations at the Leaf River at Hattiesburg, Mississippi, streamgage 02473000.

[ft³/s, cubic foot per second; ft, foot; NAVD 88, North American Vertical Datum of 1988]

\begin{tabular}{ccccc}
\hline $\begin{array}{c}\text { Discharge } \\
\left(\mathbf{f t}^{3} / \mathbf{s}\right)\end{array}$ & $\begin{array}{c}\text { Stage } \\
\text { (ft above } \\
\text { gage datum) }\end{array}$ & $\begin{array}{c}\text { Water-surface } \\
\text { elevation } \\
\text { (ft above NAVD 88) }\end{array}$ & $\begin{array}{c}\text { Simulated water- } \\
\text { surface elevation } \\
\text { (ft above NAVD 88) }\end{array}$ & $\begin{array}{c}\text { Elevation } \\
\text { difference } \\
\text { (ft) }\end{array}$ \\
\hline 33,400 & 21.34 & 139.52 & 139.64 & 0.12 \\
\hline 35,350 & 22.00 & 140.18 & 140.21 & 0.03 \\
\hline 38,530 & 23.00 & 141.18 & 141.16 & -0.02 \\
\hline 42,070 & 24.00 & 142.18 & 142.21 & 0.03 \\
\hline 45,970 & 25.00 & 143.18 & 143.13 & -0.05 \\
\hline 50,450 & 26.00 & 144.18 & 144.05 & -0.13 \\
\hline 55,200 & 27.00 & 145.18 & 145.08 & -0.10 \\
\hline 60,200 & 28.00 & 146.18 & 146.01 & -0.17 \\
\hline
\end{tabular}


Table 4. Comparison of hydraulic-model output and surveyed high-water mark elevations from the floods of April 15, 1974, and March 11, 2011, at the Leaf River at Hattiesburg, Mississippi, streamgage 02473000.

[ft, foot; mi, mile; NAVD 88, North American Vertical Datum of 1988]

\begin{tabular}{|c|c|c|c|}
\hline Flood date & $\begin{array}{c}\text { High-water mark } \\
\text { elevation } \\
\text { (ft above NAVD 88) }\end{array}$ & $\begin{array}{c}\text { Model water-surface } \\
\text { elevation } \\
\text { (ft above NAVD 88) }\end{array}$ & $\begin{array}{l}\text { Elevation } \\
\text { difference } \\
\text { (ft) }\end{array}$ \\
\hline \multicolumn{4}{|c|}{ East Hardy/South Main Street Bridge (river station 70.4 mi) } \\
\hline April 15, 1974 & 146.8 & 146.72 & -0.08 \\
\hline March 11, 2011 & 136.1 & 136.14 & 0.04 \\
\hline \multicolumn{4}{|c|}{ Southern Railroad Bridge (river station 71.2 mi) } \\
\hline April 15, 1974 & 149.7 & 149.62 & -0.08 \\
\hline March 11, 2011 & 137.8 & 137.85 & 0.05 \\
\hline \multicolumn{4}{|c|}{ USGS Streamgage 02473000 (river station 71.8 mi) } \\
\hline April 15, 1974 & 152.2 & 152.25 & 0.05 \\
\hline March 11, 2011 & 139.5 & 139.64 & 0.14 \\
\hline \multicolumn{4}{|c|}{ *Evelyn Gandy Parkway Bridge (State Highway 42) (river station 73.0 mi) } \\
\hline March 11, 2011 & 140.8 & 140.66 & -0.14 \\
\hline
\end{tabular}

*The Evelyn Gandy Parkway was constructed in 1997.

Table 5. Stages and water-surface elevations at the Leaf River at Hattiesburg, Mississippi, streamgage 02473000, with corresponding discharge estimates for selected simulated water-surface profiles.

[NAVD 88, North American Vertical Datum of 1988. Sheet numbers correspond to the separate flood-inundation maps available online at http://pubs.usgs.gov/ $\operatorname{sim} / 3300 /]$

\begin{tabular}{|c|c|c|c|c|c|c|c|}
\hline Location & \multicolumn{7}{|c|}{ Water-surface elevations and discharge estimates } \\
\hline \multicolumn{8}{|c|}{ Stage, in feet above gage datum (elevation, in feet above NAVD 88) } \\
\hline $\begin{array}{l}\text { Leaf River at Hattiesburg, MS } \\
\quad(02473000)\end{array}$ & $\begin{array}{c}22 \\
(140.18)\end{array}$ & $\begin{array}{c}23 \\
(141.18)\end{array}$ & $\begin{array}{c}24 \\
(142.18)\end{array}$ & $\begin{array}{c}25 \\
(143.18)\end{array}$ & $\begin{array}{c}26 \\
(144.18)\end{array}$ & $\begin{array}{c}27 \\
(145.18)\end{array}$ & $\begin{array}{c}28 \\
(146.18)\end{array}$ \\
\hline \multicolumn{8}{|c|}{ Discharge, in cubic feet per second } \\
\hline Leaf River at Evelyn Gandy Parkway & 25,000 & 27,600 & 30,000 & 33,000 & 36,400 & 39,500 & 43,400 \\
\hline Sheet number & 1 & 2 & 3 & 4 & 5 & 6 & 7 \\
\hline
\end{tabular}

\begin{tabular}{|c|c|c|c|c|c|c|}
\hline Location & \multicolumn{6}{|c|}{ Water-surface elevations and discharge estimates } \\
\hline \multicolumn{7}{|c|}{ Stage, in feet above gage datum (elevation, in feet above NAVD 88) } \\
\hline $\begin{array}{l}\text { Leaf River at Hattiesburg, MS } \\
\quad(02473000)\end{array}$ & $\begin{array}{c}29 \\
(147.18)\end{array}$ & $\begin{array}{c}30 \\
(148.18) \\
\end{array}$ & $\begin{array}{c}31 \\
(149.18)\end{array}$ & $\begin{array}{c}32 \\
(150.18) \\
\end{array}$ & $\begin{array}{c}33 \\
(151.18) \\
\end{array}$ & $\begin{array}{c}34 \\
(152.18) \\
\end{array}$ \\
\hline \multicolumn{7}{|c|}{ Discharge, in cubic feet per second } \\
\hline Leaf River at Evelyn Gandy Parkway & 48,900 & 57,200 & 63,400 & 70,200 & 78,000 & 85,500 \\
\hline Bouie Creek at Glendale Avenue & 20,000 & 23,300 & 25,900 & 28,700 & 31,800 & 34,900 \\
\hline $\begin{array}{l}\text { Leaf River at Hattiesburg, MS } \\
\qquad(02473000)\end{array}$ & 68,900 & 80,500 & 89,300 & 98,900 & 109,800 & 120,400 \\
\hline Sheet number & 8 & 9 & 10 & 11 & 12 & 13 \\
\hline
\end{tabular}




\section{Inundation Mapping}

Flood-inundation maps were created for 13 profiles at the USGS Leaf River at Hattiesburg Miss. streamgage (02473000), which has been designated as a NWS flood-forecast point (as of 1957). The maps were created in a GIS by combining the watersurface profiles and digital elevation model (DEM) data. The DEM data were derived from 9.84-ft horizontal resolution lidar data with a vertical accuracy of $0.6 \mathrm{ft}$ obtained from EarthData International, Inc. (written commun., 2007). Estimated flood-inundation boundaries for each simulated profile were developed with HEC-GeoRAS software (U.S. Army Corps of Engineers, 2009). HEC-GeoRAS is a set of procedures, tools, and utilities for processing geospatial data in ArcGIS by using a graphical user interface (Whitehead and Ostheimer, 2009). The interface allows the preparation of geometric data for import into HEC-RAS and processes simulation results exported from HEC-RAS (U.S. Army Corps of Engineers, 2010). USGS personnel then modified the HEC-GeoRAS results to ensure a hydraulically reasonable transition of the boundary between modeled cross sections relative to the contour data for the land surface (Whitehead and Ostheimer, 2009). The resulting inundation maps have a vertical accuracy of about $1.0 \mathrm{ft}$. The maps show estimated flood-inundated areas overlaid on high-resolution, georeferenced aerial photographs of the study area for each of the water-surface profiles that were generated by the hydraulic model.

\section{Leaf River at Hattiesburg, Mississippi, Flood-Inundation Maps on the Internet}

The flood-inundation maps described in this report and other study documentation are available online at the USGS Publications Warehouse (http://pubs.usgs.gov/sim/3300/). Also, a Flood Inundation Mapping Science Web site has been established at http://water.usgs.gov/osw/flood_inundation/ to provide a portal for USGS flood-inundation study information to the public. That Web portal has a link (http://wim.usgs.gov/ FIMI/FloodInundationMapper.html) to interactive online map libraries that can be downloaded in several commonly used electronic file formats. At the map library site, each stream reach displayed contains further links to NWISWeb graphs of the current stage and streamflow at USGS streamgage Leaf River at Hattiesburg Miss. (02473000) to which the inundation maps are referenced. A link also is provided to the NWS AHPS site (http:/waterweather.gov/ahps/) so that the user can obtain applicable information on forecasted peak stage. The estimated flood-inundation maps are displayed in sufficient detail to note the extent of flooding with respect to individual structures so that preparations for flooding and decisions for emergency response can be performed efficiently. Roadways and bridges were closely reviewed and are shown as shaded (inundated and likely impassable) or not shaded (dry and passable) to facilitate emergency planning and use. However, buildings that are shaded do not reflect inundation but denote that bare-earth surfaces in the vicinity of the buildings are inundated. When the water depth (as indicated in the Web Mapping Application by holding the cursor over an inundated area) adjacent to the building of interest exceeds that building's height, the structure can be considered fully submerged.

\section{Disclaimer for Flood-Inundation Maps}

Inundated areas shown should not be used for navigation, regulatory, permitting, or other legal purposes. The USGS provides these maps "as-is" for a quick reference, emergency planning tool but assumes no legal liability or responsibility resulting from the use of this information.

\section{Uncertainties and Limitations Regarding Use of Flood-Inundation Maps}

Although the flood-inundation maps represent the boundaries of inundated areas with a distinct line, some uncertainty is associated with these maps. The flood boundaries shown were estimated based on water stages and streamflows at selected USGS streamgages. Water-surface elevations along the stream reaches were estimated by steady-state hydraulic modeling, assuming unobstructed flow, and using streamflows and hydrologic conditions anticipated at the USGS streamgage(s). The hydraulic model reflects the land-cover characteristics and any bridge, dam, levee, or other hydraulic structures existing as of September 2013. Unique meteorological factors (timing and distribution of precipitation) may cause actual streamflows along the modeled reach to vary from those assumed during a flood, which may lead to deviations in the water-surface elevations and inundation boundaries shown. Additional areas may be flooded due to unanticipated conditions such as: changes in the streambed elevation or roughness, backwater into major tributaries along a main stem river, or backwater from localized debris. The accuracy of the floodwater extent portrayed on these maps will vary with the accuracy of the DEM used to simulate the land surface. Additional uncertainties and limitations pertinent to this study may be described elsewhere in this report.

If this series of flood-inundation maps will be used in conjunction with NWS river forecasts, the user should be aware of additional uncertainties that may be inherent to NWS forecast procedures. The NWS uses forecast models to estimate the quantity and timing of water flowing through selected stream reaches in the United States. These forecast models (1) estimate the amount of runoff generated by precipitation and snowmelt, (2) simulate the movement of floodwater as it proceeds downstream, and (3) predict the flow and stage (and water-surface elevation) for the stream at a given location (AHPS forecast point) throughout the forecast period (every 6 hours and 3 to 5 days out in many locations). Each of these steps involves some degree of approximation so results should be applied with allowances for possible error. For more information on AHPS forecasts, please see: http://water.weather.gov/ahps/pcpn_and_river_forecasting.pdf. 


\section{Summary}

Estimated flood-inundation maps were developed in cooperation with the City of Hattiesburg, City of Petal, Mississippi Emergency Management Agency, Mississippi Department of Homeland Security, and the Emergency Management District for the Leaf River at Hattiesburg, Miss. These maps, in conjunction with the real-time stage data from the USGS streamgage at Leaf River at Hattiesburg, Miss. (station no. 02473000) and flood-stage forecasts by the National Weather Service, can be used to guide the general public in taking individual safety precautions and will provide city officials with a tool to efficiently manage emergency flood operations and flood mitigation efforts. These maps supersede previously published flood-inundation estimates to include reaches above the confluence of the Bouie and Leaf Rivers.

The maps were developed by using the U.S. Army Corps of Engineers' HEC-RAS and HEC-GeoRAS programs to compute water-surface profiles and to delineate estimated flood-inundation areas for selected stream stages. The maps show estimated (shaded) flood-inundation areas overlaid on high-resolution, georeferenced aerial photographs of the study area for stream stages between 22.0 feet and 34.0 feet at the Leaf River at Hattiesburg Miss. streamgage. The maps are available at a USGS Web portal at http://pubs.usgs.gov/sim/3300/. Interactive use of the maps by using the mouse cursor to click within the shaded areas can give users a general indication of depth of water at any point.

\section{References Cited}

Bales, J.D., Wagner, C.R., Tighe, K.C., and Terziotti, Silvia, 2007, LiDAR-derived flood-inundation maps for realtime flood-mapping applications, Tar River Basin, North Carolina: U.S. Geological Survey Scientific Investigations Report 2007-5032, 42 p.

Federal Emergency Management Agency, 2010, Flood insurance study, Forrest County, Mississippi and incorporated areas: $79 \mathrm{p}$.

Storm, J.B., 2012, Flood-inundation maps for the Leaf River at Hattiesburg, Mississippi: U.S. Geological Survey Scientific Investigations Map 3228, 8 p. pamphlet, 13 sheets (Also available at $h$ ttp://pubs.usgs.gov/sim/3228/.)

U.S. Army Corps of Engineers Hydrologic Engineering Center, 2009, HEC-GeoRAS, GIS tools for support of HEC-RAS using ArcGIS-User's manual, version 4.2 [variously paged].

U.S. Army Corps of Engineers Hydrologic Engineering Center, 2010, HEC-RAS River Analysis SystemHydraulic reference manual, version 4.1 [variously paged].

U.S. Army Corps of Engineers, 1983, Leaf and Bouie Rivers Hattiesburg and Petal, Mississippi: Detailed Project Report and Environmental Impact Statement, 267 p.

U.S. Census Bureau, 2010, State population datasetsPopulation, population change and estimated components of population change: 2000 to 2010 (http://quickfacts. census.gov/qfd/states/28000.html).

Whitehead, M.T., and Ostheimer, C.J., 2009, Development of a flood-warning system and flood-inundation mapping for the Blanchard River in Findlay, Ohio: U.S. Geological Survey Scientific Investigations Report 2008-5234, 9 p.

Wilson, K.V., 1964, Floods of 1961 in Mississippi: U.S. Geological Survey Bulletin 64-4, 93 p. 
Manuscript approved on May 9, 2014

Edited by Michael Deacon Layout by Caryl J. Wipperfurth

Science Publishing Network Raleigh Publishing Service Center

For more information about this publication, contact: Director, Mississippi Water Science Center U.S. Geological Survey 308 Airport Road South Jackson, MS 39208-6649 (601) 933-2900

http://ms.water.usgs.gov/ 
